\title{
SME Financing: IPO ISSUE AND POST-IPO ANALYSIS
}

\author{
Effulgence \\ Vol. 16 (Special Issue) \\ January - June, 2018 \\ Rukmini Devi Institute of Advanced Studies \\ E-mail : effulgence@rdias.ac.in, Website : www.rdias.ac.in \\ http://effulgence.rdias.ac.in/user/default.aspx \\ https://dx.doi.org/10.33601/effulgence.rdias/v16/iSpl1/2018/article0.8
}

\begin{abstract}
Ashish Sharma, AIM A AM U Phd Scholar, 198ashish@gmail.com
Prashant G upta, A ssociate Professor at I M I, Delhi, prashantgupta@imi.edu
\end{abstract}

\begin{abstract}
Small Medium Enterprises (SMEs) are an engine of growth for any nation in the world. As per estimates of World Bank, 45\% of total employment is created by formal SMEs and approximately up to 33\% of national income (GDP) in emerging economies. This calculation may further inflate if contribution of informal SMEs is included. As per estimates $\sim 600$ million jobs will be required in the coming 15 years to provide employment to the growing manpower worldwide, primarily in Asia and Sub-Saharan Africa. In emerging markets, SMES provide most of the formal jobs. Therefore, access to finance is a key constraint to SME growth; without it, many SM Es suffer and stagnate.
\end{abstract}

Recently, an initiative has been taken for the capital financing of SMEs via IP Os, wherein the response has been very good and encouraging. Also, the performance of secondary market of SME IPOs has been very good. But the low level of liquidity and turnover makes the whole process risky for investors. This is why SEBI (market regulator in India) has issued directives that while investing in SME IPOs, small investors should be kept away. SEBI further reiterates that merchant bankers should act as investors in such companies for at least three years. On the flipside, if these three years goes on in only settling the whole business, the interest of these shareholders may vanish and they may withdraw their investment. This will lead to liquidity crunch again. This paper focuses on measuring the effectiveness of SME financing through IPO and analysing how successful companies have been after raising finance through this route. Also, examining how the involvement of stock exchanges, where these companies are listed, may provide sustained support to the managements of these companies.

Keywords: BSE SM E IPO, SM E Exchange, SM E E mployment, SM E growth

\section{INTRODUCTION}

Contribution to different economic factors such as GDP, industrial growth, employment, and exports, make small and medium enterprises (SMEs) a part and parcel of our economy. SME sector acts like an insulin to emerging economies of the world and hence their role and contribution become more important similar to a large corporation. Despite such an important factor, it suffers from various challenges such as lack of funds, availability of credit and limited access to equity. They have been dependent on bank lending to a large extent to meet their day to day requirements of funds. Although some of the help is provided by Small Industries Development Bank of India (SIDBI) in terms of equity capital. This assistance acts as a temporary heal rather than having a permanent solution for capital. In such a case, a common platform is required where fund takers and fund providers can meet and serve as complementary to each other. L arge corporations have many options to meet their funding requirements such as IPO, FPO, private placement, debt financing etc., whereas SMEs don't have such advantages. History holds enough evidence that SMEs have always struggled to meet their financing needs. In past alternate funding methods have been adopted such as the establishment of Over the Counter Exchange of India (OTCEI) in 1990 and the INDO NEXT Platform of the BSE started in 2005, but these did not prove to be successful in their aim (SEBI 2008). This led to the formation of BSE SME platform by BSE in M arch 2012 and SME platform 'Emerge' by N SE in September 2012.

The objective of this paper is to analyse the performance of SME exchanges in India and find out if IPO as a route of financing for SMES is successful or not. This paper throws light on the international scenario of SME exchanges, regulatory guidelines regarding equity resource mobilization by SMES through IPOS, the importance of the primary $\&$ secondary market in 
recently launched SME platforms and a financial overview of listed companies.

\section{LITERATURE REVIEW}

One of the interesting phenomena in SME financing is the role of IPO and its effect on companies' performance. Since SME's role has been accepted worldwide by various countries as a reason of boost to economy and trade, a lot of research and whitepapers have been written in this field. In the opinion of C B B have (2010) (speech delivered at $\mathrm{FICCI}$ ), SMEs are a catalyst in the majority of the economies and form a significant part of industrial activity. He further reiterates that since SMEs in most of the cases come across financial crisis, therefore, he anticipates that the formation of SME Exchange will be an important step to provide support in terms of capital, enhanced credibility and other benefits.

Review of literature explains that banks are the primary source of capital for SMEs in both developed and developing countries (Vera \& Onji, 2010; Ono \& U esugi, 2009; Zhou, 2009; Wu et al., 2008; Carey \& Flynn, 2005; Cole \& W olken 1995). Also, everybody had been focussing on the concern that similar to large corporations, SM Es should be promoted as an active participant in IPO to ease availability of finance.

R. K. Jain, A vdhesh Kumar Shukla and Kaushiki Singh (2013), in a whitepaper at RBI, have analysed the importance of IPO and some of the financial attributes of listed companies. While measuring the performance of companies after IPO, most of the research carried out harmonizes with research in the US by Moonchul and Ritter (1999) that after IPO, companies performance generally either remains stagnant or underperform in terms of revenue and market capitalisation in the market. However, Loughran and Ritter (1995) presents a different picture that underperformance is not something that is inherent post-IPO, there have been instances when their market capitalisation has shown consistent Compounded annual growth (CAGR) viz-a-viz net income.

While citing the importance of SMES Y Srinivas (2005), mentioned in an article in ICAI journal that SMEs play an important role in the economy bringing parity between balanced and sustainable growth, employment generation, entrepreneurial skills development and contribution to export earnings. However, in spite of their significance to the economy, most SMEs face the brunt of globalisation, primarily due to problems in the area of financing. He further emphasized that since globalisation in 1991, it has become very important to smoothen up the flow of credit to this sector.
Keshab Das (2007) has studied that in spite of descriptive and active policy framework in India, the growth of SMEs continues to be slowed down by fundamental problems such as poor availability of funds, low levels or obsolete technology, which affects the quality of product and hence lesser exports. He stressed on the fact that it would be too early to judge the effectiveness of new policies. He says that much of the potential of small firms to grow and develop innovativeness is formed by the type of infrastructure, both physical and economic, available and can be accessed at reasonable costs. The MSMED ACT gives more importance to networking with stakeholders both upstream and downstream in the entire global value chain, starting from obtaining of raw material, handling/production to marketing and customer services.

B hatendra Kumar Gupta (2008) and Tarak Shah (2011), in their research study, said that after agriculture, the SME sector is the second largest employer in India. For making anything successful, the role of financing or funding is eminent and this calls for a need of a dedicated stock exchange for the MSME sector to cater to their requirements. This problem of insufficient financing to SMES needs serious attention amongst the others to ensure adequate credit delivery to SM Es, better risk management, and technological up gradation. The SMEs sector is considered to be an unexploited market for financial organizations in India. The only way out of the mire is that the Indian manufacturing sector could be supported by the current rural systems and by making them selfsufficient. This is only possible by helping small \& medium enterprises and the rural artisans (people with innate skills and talents) in becoming effective and competitive enough to face the future. A number of problems and business practices of global players and markets can be witnessed, learnt and adjusted for ensuring the competitiveness of Indian SM Es.

\section{RESEARCH PROBLEM}

It was observed that there is a body of literature in the SME financing through IPO in foreign markets and their effects on companies. However, it remains unknown the extent to which these initiatives are beneficial in Indian scenario and how this route has succeeded in addressing the needs of funding and enhanced visibility of companies listed on these exchanges. Through this paper, we aim to understand the benefits of launching SME exchanges and how companies are reaping advantages of this initiative. Hence, this research is useful in understanding the importance of SME 
exchanges, and measuring the effect of IPO on SMES.

\section{METHODOLOGY}

The research conducted is descriptive in nature. From a total of 207 companies listed as of 19 October 2017 on BSE SME exchange, financial data of at least last three financial years for only 169 companies was available. The probable reason could be that either few companies have stopped trading or migrated to main exchange or listed at a later date. BSE SME exchange was started in Jul 2012. In the initial years, there was only handful of companies which were listed and data availability was scarce. Therefore, data of 169 companies has been used throughout the paper. On the other side, 88 companies are listed at N SE Emerge, therefore, volatility at NSE Emerge is less than BSE SME. In this case, an index having high volatility makes more sense to be taken for study.

To carry out the study, data has been collected from annual reports of listed companies, journals, and different stock exchange websites.

\section{SME FINANCING CONCERNS}

In a discussion paper by SEBI, several factors have been identified which highlight the need for SME financing rising role of an exchange as under:

- High cost of raising capital

- As compared to large corporations, SM Es do not have access to funds from angel investors, VCs, and PE players

- In case of smaller issues, the costs of raising capital as per current guidelines are fixed, which become troublesome for smaller issues (SM Es)

- A strong framework is required for SMEs to fasten the process of raising capital at a low cost

- Due to small size and less affordability, the eligibility norms, listing requirements, corporate governance norms and other formalities may need to be relaxed for SMES

\section{INTERNATIONAL SCENARIO}

Globally, separate exchanges have been established to cater to the needs of SMES and facilitate their growth and funding requirements. From a total of 192 countries known globally, 149 have their own stock exchange. And among those countries roughly 57 have an alternative markets for SME companies to raise funds. Some of the examples are:
1) Alternative Investment M arket - AIM (London Stock Exchange, London): Established in 1995 as a sub-market of the London Stock Exchange. Over 3,600 companies have chosen to join AIM since inception. It helps companies from Canadian oil explorers to Chinese tech start-ups. A Iso, a number flexibility is provided in this exchange such as no minimum size requirements for listing and shares can be traded in any freely-available currency, etc. 2) NASDAQ OMX First North (NASDAQ OMX Group): Designed for small and growing companies, where every company has a Certified Adviser, who is responsible for carrying out the whole process of listing. This exchange is very much suitable for small, young or growth companies. NASDA Q OMX First North integrates the advantage of becoming public without any hassle and is mainly considered as the first step towards the main market. (NASDAQ OMX website).

3) NYSE Alternext (NYSE-Euronext Group): Formed in 2005 by Euronext to meet the needs of small and midsized companies. Here the rules are as easy with a minimum free float requirement of $€ 2.5 \mathrm{~m}$ only for IPO. On the other side, for a private placement, the company can apply for listing on A Iternext and must prove that they have placed at least $€ 5 \mathrm{~m}$ with five or more investors.

4) Euro MTF (The Luxembourg Stock Exchange, L uxembourg): Acts as a major listing centre of international bonds, equities, and other funds. The L uxembourg Stock Exchange functions through two markets: European regulated market (opened in M ay 1929) and Euro M TF (opened in July 2005 and is a multilateral trading facility regulated by the exchange itself.

5) Mothers (Tokyo Stock Exchange, Tokyo): Established in 1999 under M others name (market of the high-growth and emerging stocks), to meet early stage funding requirements of venture companies and offer investors with more diversified investment products. Here the leadunderwriter submits a written, TSE-designated format statement, to TSE called 'Sponsor's Letter of Recommendation' on behalf of an applicant, stating the fact or reason as to why the applicant meets the eligibility criteria of strong growth potential and in which of its primary field of business such high growth potential is observed.

6) TSX V enture Exchange (TMX Group, Canada): This exchange was formed to provide public venture capital to expedite the growth process of new ventures. Listing in the current exchange opens up the opportunity to access larger pools of capital. 
7) The A Iternative Exchange (Johannesburg Stock Exchange, South Africa): Caters to the requirements of a large number of companies in all sectors including young $\&$ fast-growing businesses (such as start-ups) and family-owned businesses.

8) Growth Enterprise M arket (Hong K ong, China): The Growth Enterprise Market does not require growth companies to fulfil the requirements to have achieved the minimum profit levels as a condition of listing.

If we look at the listing requirements of SME exchanges, almost all the markets adopt an easy process of listing and maintenance requirements than the main market, in terms of various parameters: operating history, the minimum number of shareholders, past financial performance and number of free-float shares, etc. To maintain sufficient liquidity, many exchanges have put across alternative arrangements such as market makers for liquidity. While making policies related to the SM E Exchange in India, several of the global practices have been adopted.

\section{DOMESTIC SCENARIO}

OTCEI - Over the Counter Exchange of India: Started in 1990 \& initiated trading two years later to provide a gateway for small \& medium enterprises entry into capital markets. Listing requirements \& other charges at OTCEI is as follows (Yogendra Sisodia, SME Exchanges Platforms 2009):

- OTCEI is the only exchange in the country that allows listing of company with a paid-up equity capital of at least Rs.30 lakhs, whereas no higher limit has been fixed on the capital to be raised

- OTCEI is preferably suitable for start-up enterprises as 3-year track record is not mandatory

- Listings on OTCEI do not require startup companies to have $10 \%$ equity / debt participation by banks / financial institutions.

- OTCEI charges Rs.7500/- for initial listing, besides an annual fees depending upon the paid up capital
Indonext: BSE IndoNext was established in January 2005 to benefit small \& medium size companies, the investors in these companies $\&$ the capital market as a whole. Basic features are as follows:

- The concept is based on the Euronext exchange, which was formed in 1999 by merging the Paris, A msterdam, Lisbon \& $B$ russels stock exchanges

- Investors \& the companies, which are listed only on Regional Stock Exchanges (RSEs) have been impacted severely, as the volatility at RSEs is very low and they record insignificant trading volumes. Investors who make investments in such small \& medium companies feel helpless to take their money out due to less volatility $\&$ unable to realize the fair value of their investments.

- The companies listed only at RSEs face difficulty in raising finance from the capital markets due to improper price discovery of securities in the secondary market. New small \& medium enterprises (SMEs) have not been able to use the markets to fund their plans.

\section{REGULATORY REQUIREMENTS ON LISTING OF SMES IN INDIA}

India has developed its SME platforms after learning serious lessons from the global platforms. Difficulties faced by global SME exchanges, OTCEI's \& Indonext's experience, as well as domestic conditions of capital market, have provided an important base for the formation of SME exchanges in India (BSE 2011). According to SEBI, SME exchanges should be set up as corporatized entities (bodies with a structure found in publicly traded firms) with a minimum net worth of Rs.1,000 million. These guidelines stipulate that an issuer with post-issue face value of up to Rs.100 million will be invariably covered under the SME exchange whereas issuers with post-issue face value capital between Rs.100 million and Rs.250 million may get listed either on the SME exchange or on the main board (Table 1) (Y ogendra Sisodia, SM E Exchanges Platforms 2009).

Table 1: Listing Criteria - M ain Board and SME Exchange

\begin{tabular}{l|l|l}
\hline Parameters & SME Exchange & Main B oard \\
\hline
\end{tabular}




\begin{tabular}{l|l|l}
\hline Basis of Difference & BSE SM E Exchange & BSE M ain B oard \\
\hline $\begin{array}{l}\text { Post-issue paid up capital } \\
\text { (face value) }\end{array}$ & $\begin{array}{l}\text { M inimum post issue capital of 1 crore } \\
\text { and maximum 25 crores }\end{array}$ & $\begin{array}{l}\text { M inimum post issue paid up capital of 10 } \\
\text { crores }\end{array}$ \\
\hline M inimum A llottees in IPO & 50 & 1000 \\
\hline IPO Grading & Non- M andatory IPO Grading & M andatory IPO Grading \\
\hline IPO Underwriting & $\begin{array}{l}\text { M andatory (100\% underwritten with } \\
\text { M erchant B anker underwriting 15\%) }\end{array}$ & $\begin{array}{l}\text { Non- M andatory (Under 50\% compul sory } \\
\text { subscription to Q IB's) }\end{array}$ \\
\hline Track Record & Relaxed norms & Stringent norms \\
\hline Offer Document V etting & By Stock Exchange & By SEBI \\
\hline IPO A pplication Size & M in Rs.1,00,000/- & Rs.10,000 - Rs.15,000 \\
\hline IPO Timeframe & 3 to 4 months & 6 months onwards \\
\hline Reporting Requirement & Half yearly & Quarterly \\
\hline
\end{tabular}

Source: BSE SME Website

There are two important distinguishing attributes between OTCEI and present SM E exchanges:

1) Unlike OTCEI, which was standalone, now SME exchanges are completely integrated with a particular exchange and allow easy migration from the SM E platform to the primary exchange

2) There is a $100 \%$ provision for underwriting of the issue and market maker for three years after the listing to provide liquidity (SM E W orld 2014).

SEBI has worked hard to decide upon relaxed norms regarding listing on the SM E Exchange such as issuers need not have a track record of distributable profits. As of now, the present procedures set up by SEBI is based on following objectives: a) to protect investor's interest by keeping larger lots, to limit the participation only to informed investors, b) maintaining sufficient liquidity by provision of market making and c) involving a merchant banker to file red herring prospectus (RHP) with due diligence certificate with the exchange, this will reduce the time involved in the processing of issue (BSE 2011).

\section{BENCHMARK: SME IPOS PERFORMANCE IN THE SECONDARY MARKET}

Along with SME platform, BSE has set up a barometer index under the name BSE SME IPO to keep a track on the performance of SME IPOs in the secondary market. The BSE SME IPO Index is calculated with free float methodology in line with other BSE indices. The number of scrips included in the index is variable. However, at any point of time, a minimum of 10 companies should be maintained in the index. All newly listed companies are incorporated in the index and a company which has completed three years after listing is automatically excluded from it. The index was launched on 14 December 2012 and started trading on $18 \mathrm{~J}$ an 2013. From a period of trading till 19 Oct 2017, the BSE SME index witnessed a huge rally of about $1085.2 \%$ which is significantly higher than gains in other stock indices in India. The performance of BSE SM E Index can be seen in Figure 1 below, showing comparison with and primary index BSE Sensex: 
Figure 1: BSE SME IPO Performance

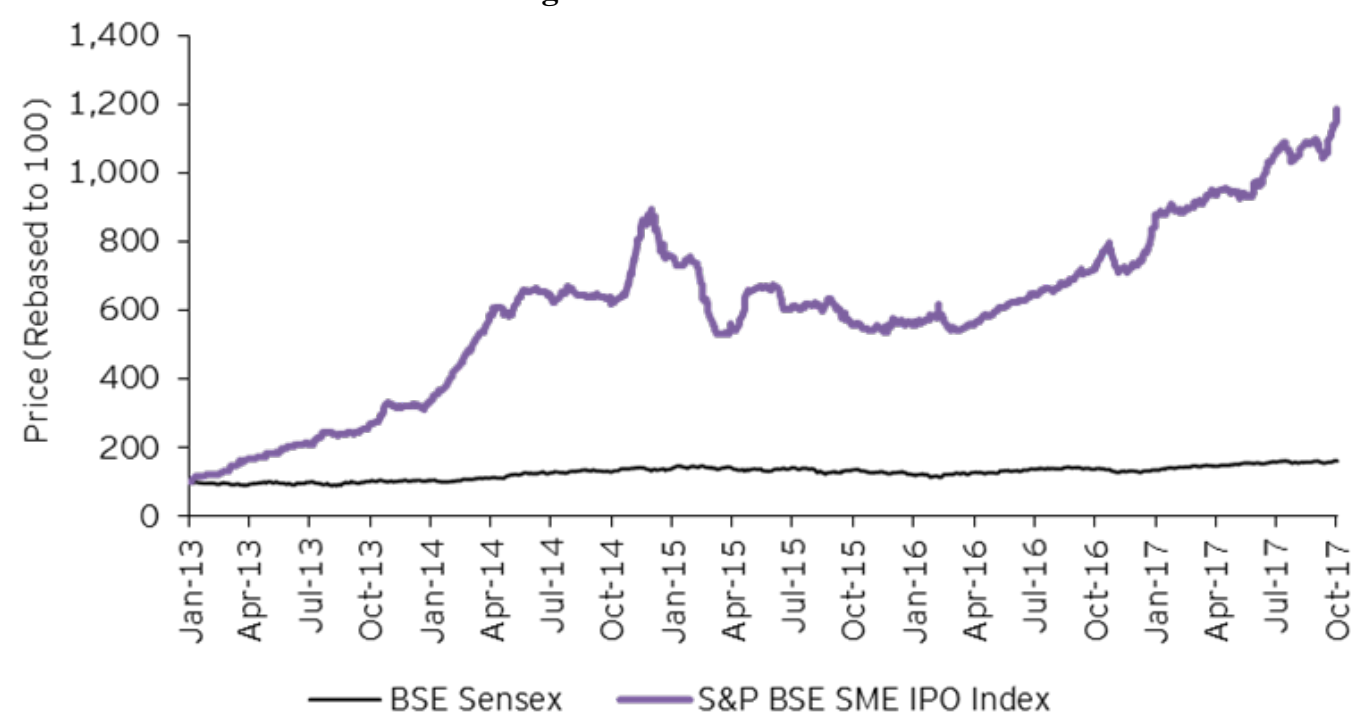

Source: BSE SME \& BSE Website

\section{SECTORAL DISTRIBUTION OF COMPANIES AND FINANCIAL EFFECTS ON PERFORMANCE OF COM PANIES LISTED ON SME PLATFORMS}

A pproximately there is a list of 207 companies' scrips available on BSE SME website (as of 19 Oct 2017). A snapshot of company details is available below:

Table 2: BSE SME M arket Statistics (as on 190 ct 2017)

\begin{tabular}{|l|l|}
\hline No. of companies listed on SM E till date & 207 \\
\hline N o. of companies migrated to main board & 34 \\
\hline N o. of companies listed as of date & 173 \\
\hline N o. of companies suspended & 4 \\
\hline No. of companies eligible for trading & 169 \\
\hline M kt Cap of BSE SM E Listed Cos. (Rs.Cr.) & $11,590.7$ \\
\hline
\end{tabular}

Source: BSE SME Website

Since the opening of BSE SME and NSE Emerge exchanges, BSE SME has been able to establish itself as a preferred platform for listing. Below graph shows the sector wise breakup of companies listed at BSE SME. Sectoral distribution of 207 companies reveals that primarily financial companies (16, including other financial services companies), Textiles (11) and Comm. Trading \& Distribution (10) have shown interests to mobilize resource from the market. Further, a most of the companies belong to the services sectors which are considerably diversified. This diversification of listed firms is important from the risk management point of view of SME platforms as well as for investors.

The volatility is more at BSE SME than NSE Emerge. Only half of the companies have been listed at NSE E merge till now. Here for the purpose of analysis, companies at BSE SME have been taken. From a total of 207 companies, 169 companies have been taken for the purpose of financial analysis because the financial data of only 169 companies for four years was available. 


\section{Figure 2: Sector-wise Distribution of $L$ isted Companies}

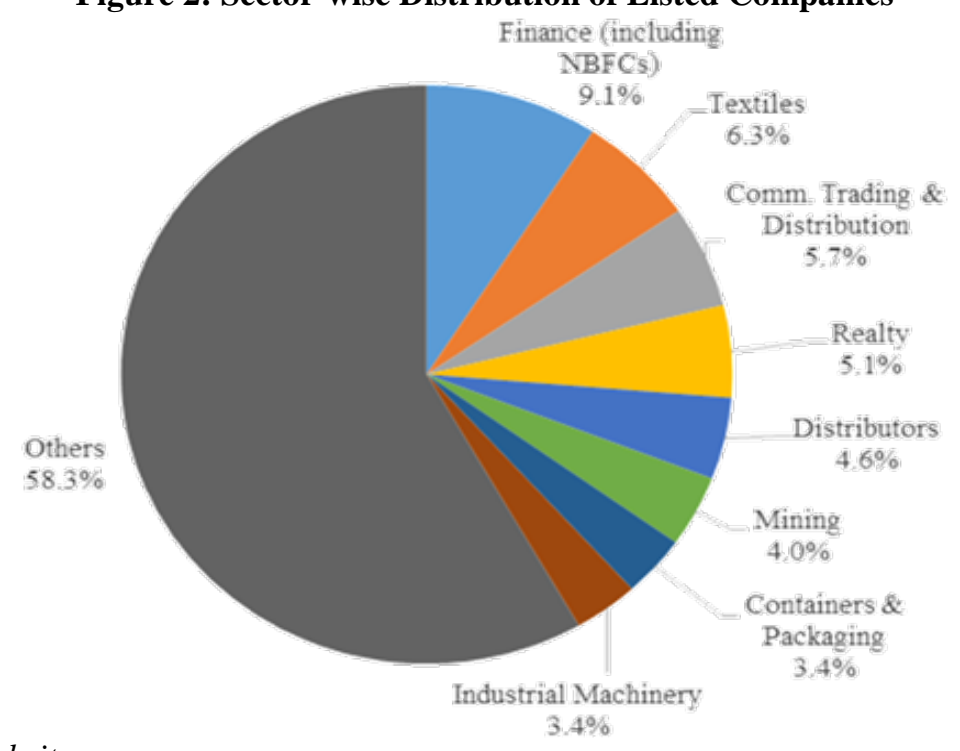

Source: BSE SME Website

Following are the primary financial attributes which have been analysed for companies listed in BSE SME:

1. Market Capitalisation: Since these companies operate at a small level, market capitalisation stands at an average of Rs.676m with highest being Rs.10,232m. A round 24 companies had a market capitalization between Rs.1,000-10,500m, constituting $\sim 14 \%$ of the total companies under consideration. The large market cap is an indication of the size of the company. Companies with large market capitalization usually have more assets, capital and higher revenues than those having smaller market capitalization. Top five companies with highest market capitalisation have been shown below:

Table 3: Top Five Companies with H ighest M arket Capitalisation

\begin{tabular}{lc}
\hline Companies & M arket Cap (R s. million) \\
\hline Vishal Fabrics Ltd & 10,232 \\
\hline Esteem Bio Organic Food Processing Ltd. & 7,931 \\
\hline HPC B iosciences Ltd. & 7,286 \\
\hline Channel Nine Entertainment Ltd. & 5,287 \\
\hline Eco Friendly Food Processing Park Ltd. & 5,275 \\
\hline
\end{tabular}

Source: Author Analysis

2. Price-earnings ratio (P/E): A comparison of the P/E ratio of SME companies as on 19 Oct 2017, 24 companies had P/E ratio of greater than 100, which is an average of all companies. Investors are generally willing to pay a higher P/E for companies whom they think will be growing at a higher rate than the normal growth. High P/E ratio of these companies shows confidence in the investors that these companies are on the verge of growth. Top 24 companies having high P/E ratio are:

Table 4: Top 24 Companies with Highest P/E ratio

\begin{tabular}{|l|c|}
\hline Companies & P/E ratio \\
\hline Pure Giftcarat Ltd & 261 \\
\hline Manas Properties Ltd & 224 \\
\hline Stellar Capital Services Ltd & 182 \\
\hline Shiva Granito Export Ltd & 179 \\
\hline Anisha Impex Ltd & 178 \\
\hline
\end{tabular}




\begin{tabular}{|l|l|}
\hline Prime Customer Services Ltd & 165 \\
\hline Suncare Traders Ltd & 160 \\
\hline R\&B Denims Ltd & 159 \\
\hline Veeram Ornaments Ltd & 157 \\
\hline Unishire Urban Infra Ltd & 156 \\
\hline Relicab Cable Manufacturing Ltd & 150 \\
\hline O. P. Chains Ltd & 148 \\
\hline Amrapali Fincap Ltd & 137 \\
\hline VMV Holidays Ltd & 131 \\
\hline Karnimata Cold Storage Ltd & 127 \\
\hline Amrapali Capital and Finance Services Ltd & 126 \\
\hline Captain Pipes Ltd & 117 \\
\hline Zeal Aqua Ltd & 117 \\
\hline Poojawestern Metaliks Ltd & 116 \\
\hline B.C. Power Controls Ltd & 115 \\
\hline Jet Infraventure Ltd & 111 \\
\hline Vaksons Automobiles Ltd & 110 \\
\hline Aditya Consumer Marketing Ltd & 107 \\
\hline Polymac Thermoformers Ltd & 101 \\
\hline
\end{tabular}

3. Revenue growth: For a number of companies listed in last three years (i.e. 2017, $2016 \& 2015$ ), average growth in revenue from the time of listing till 2017 had been tremendous.

$\begin{array}{ccc}\text { Listing Year } & \text { No. of Companies } & \text { Average Growth in Revenue } \\ 2015 & 32 & 2,088 \% \\ 2016 & 43 & 1,326 \% \\ 2017 & 44 & 352 \%\end{array}$

The above analysis clearly shows that post-IPO, the majority of the companies have witnessed unprecedented growth in revenue. Difference between is a maximum of three years and such a drastic growth is spectacular for all companies. It means that by raising finance through IPO, they have been able to see a significant rise in their revenue. It is also an evidence of the fact that post-IPO, the companies gain visibility in the eyes of consumers too.

4. Institutional Holdings: M ostly in $58 \%$ of sampled companies, the promoters have held more than $50 \%$ stake in their companies. A major holding by financial institutions confirms good governance and greater answerability, which was primarily absent in most of the enterprises. Involvement of institutional investors, who usually take investment decisions after carefully analysing the feasibility of business prospects of the issuers, will propel more retail investors to come and invest in SME issues with confidence.

Listing Year
2015
2016
2017

No. of Companies
$\begin{aligned} & 32 \\ & 43 \\ & 44\end{aligned}$

\section{Average Growth in Net Income \\ $612 \%$ \\ $231 \%$ \\ $558 \%$}

5. Net Income: For a number of companies listed in last three years (i.e. 2017, $2016 \& 2015$ ), average growth in N et Income from the time of listing till 2017 had been commendable.

Net Income CAGR of $\sim 119$ companies witnessed an average growth of $467 \%$. This implies that SMEs have more opportunity with them to expand further.
The above analysis of publicly available financial attributes emphasizes the fact that there has been a significant effect of IPO on companies' performance. Most of the players had sought finance for meeting working capital requirements. 
Here the role of exchange increases in terms of transparency. Exchanges may also provide handholding to the companies listed with them. They may also provide fundamental and technical

\section{RESEARCH IM PLICATIONS}

The present analysis helps us in understanding how SMES are benefitted by IPO issue. The study has been conducted for the 169 companies for which data was available. The post-IPO issue is on the rise as awareness is increasing amongst SM Es. The study reveals that primary objective of reaching out to market is to raise capital for meeting the requirements of working capital, gain visibility, and favourable treatment when borrowing from a financial institution. These were some of the factors which primarily affect the desire for SM Es to seek finance from the market. In future, as more companies get listed, factors motivating companies to get listed may also increase or decrease. These factors could be raising finance to make themselves lucrative for venture capital ists to invest money and enhance visibility as a target company for buyers. This study can be further extended to include more companies and analyse more variables under the ambit of research and study their effect on the companies listed on the market.

\section{CONCLUSION}

The SME Capital market in India has seen a flurry of activities in past 4.8 years. SME Platform has opened up massive opportunities for SMEs to maximize wealth and enhance visibility and opened up new investment avenues for investors. Participation has also been from diverse sectors, with a major contribution from service sector itself. These SME capital market platforms are still in nascent stage and will evolve as changes in markets become more transparent and newer practices develop. Nevertheless, SME entrepreneurs have also got a fresh ray of hope for raising capital in a reasonable and tax efficient manner and take their organisation to the next level of growth. In the process, this opens up as an enormous opportunity for all participants of the market including market intermediaries and professionals.

Due to an important role of SMEs in the economy, government and regulatory bodies aim to provide adequate flow of financial resources as a priority to them. An analysis of SME issues listed on SME platforms shows that their initial performance has been encouraging and they have grown significantly in terms of revenue, net income and overall profitability. As visible from the diagram of the performance of BSE SME IPO (Figure 1), a sharp rally indicates good prospects for the future research support in partnership with various brokerage houses on the financial attributes of these companies on a regular basis which will reduce information irregularity about them.

and opens up an encouraging scenario for fresh SMEs thinking to get listed. One important thing was observed that only investors who have proper knowledge and understanding of the market and its benefits are only taking steps to come forward and participate in IPO process. In this case, the role of exchange becomes very important to educate them and act as a facilitator when they are involved in the IPO process.

The increasing role of merchant bankers as a major participant in the process makes whole process market driven and ensures liquidity in the market. However, the ownership involvement should be increased from three years to five years so that confidence of SM Es is maintained. SME exchanges role is of utmost importance to ensure overall transparency and sustainability in the system.

The study was limited to companies whose financials for at least three years were available post-IPO. As more companies are listed scope of this study can be extended further to measure the effectiveness of SME exchanges in India and measure post-IPO performance.

\section{REFERENCES:}

1) AIM. (2016, May 06). Retrieved from http://www.aimlisting.co.uk/index.php/pa ge $/ T$ he-A im-M arket.

2) B ombay Stock Exchange (2011). Retrieved from http://www.bsesme.com/downloads/ BSE_SME_EBOOK.pdf.

3) BSE Indonext. (2016, M ay 06). Retrieved from www.bseindia.com/Static/about/indonext. aspx? expandable $=2$

4) Carey, D., \& Flynn, A. (2005). Is Bank Finance the A chilles' Heel of I rish SM Es? J ournal of European Industrial Training, $29 \quad(8 / 9), \quad 712$. http://dx.doi.org/10.1108/0309059051062 9849

5) Cole, R. A., \& Wolken, J. D. (1995). Financial Services U sed by Small Businesses: Evidence from the 1993 National Survey of Small Business Finances. Federal Reserve Bulletin, $\mathrm{V}$ ol. $81,629-667$.

6) Das, K. (2008), 'SM Es in India: Issues and Possibilities in Times of Globalisation', in Lim, H. (ed.), SME in 
Asia and Globalization, ERIA Research

Project Report 2007-5, pp.69-97.

A vailable at:

http://www.eria.org/SM Es\%20in\%20India Issues $\% 20$ and $\% 20$ Possibilities $\% 20 \mathrm{in} \% 2$

0T imes\%20of\%20G lobalisation.pdf

7) Growth Enterprise Market Hong Kong Market. (2016, May 06). Retrieved from www.hkgem.com/

8) Jain, R. K., Shukla, A., \& Singh, K. (2013). SME Financing through IPOs An Overview. Reserve Bank of India Occasional Papers. Vol. 34, \# 1 \& 2. Retrieved from https://www.rbi.org.in/scripts/bs_viewcont ent.aspx? Id=3055

9) Junjie Wu, Jining Song, Catherine Zeng, (2008) "An empirical evidence of small business financing in China", Management Research News, Vol. 31 Iss: 12, pp.959 - 975

10) List of scrips and index prices. (2016, M ay 06). Retrieved from http://www.bsesme.com/listing.aspx

11) L oughran, T. and Ritter, J.R. (2002), “Why don't issuers get upset about leaving money on the table in IPOs?", Review of Accounting Studies, Vol. 15 No. 4, pp. 413-43.

12) Mothers, Tokyo Stock Exchange, Tokyo. (2016, May 06). Retrieved from www.jpx.co.jp/english/equities/products/f oreign/mothers/

13) NASDAQ OMX. (2016, May 06). Retrieved from www.nasdaq.com

14) NYSE Alternext. (2016, May 06). Retrieved from https://www.euronext.com

15) Ono, A., \& Uesugi, I. (2009). Role of Collateral and Personal Guarantees in Relationship Lending: Evidence from Japan's SME Loan Market. Journal of Money, Credit and Banking, 41(5), 935-

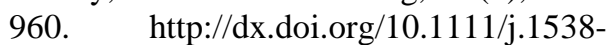
4616.2009.00239.x

16) OTCEI. (2016, May 06). Retrieved from www.otcei.net/

17) Prospectus of listed at BSE SME. (2016, May 06). Retrieved from www.bsesme.com.

18) SEBI. (2016, May 06). Retrieved from http://www.sebi.gov.in/commreport/sme.p df

19) Shukla, T. N ., \& Pattanaik, D. (2015, October). A Case Study on Conceptual Framework of Lending Technologies for Financing of Small and M edium Enterprises. Indian 0 verseas Bank. Retrieved from http://ijemr.in/A \%20Case\%20Study\%200 n\% 20C onceptual \% 20F ramew ork $\% 20$ of $\%$ 20L ending\%20T echnologies $\% 20$ for $\% 20 \mathrm{~F}$ inancing $\% 20$ of $\% 20$ Small $\% 20$ and $\% 20 \mathrm{Me}$ dium $\% 20$ Enterprises $\% 20$ by $\% 20$ Indian $\% 2$ 00 verseas\%20B ank.pdf

20) Srinivas, Y. (2005, September). B ank Finance to the SME Sector- Issues And Perspectives. Retrieved from http://www.icaiejournal .org// ournal/1134_ 2005 9.pdf

21) Stock Exchange of Hong Kong. (2016, $M$ ay 06). Retrieved from http://www.hkgem.com/aboutgem/e_defau It.htm? $\mathrm{ref}=7 \% 3 \mathrm{~A}$.

22) The Alternative Exchange, J ohannesburg Stock Exchange, South Africa. (2016, $M$ ay 06). Retrieved from https://www.jse.co.za/capital/altx

23) Tokyo Stock Exchange. (2016, M ay 06). Retrieved from http://www.tse.or.jp/english/rules/mothers

24) TSX Venture Exchange, TMX Group, Canada. (2016, M ay 06). Retrieved from https://www.tmx.com/

25) Vera, D., \& O nji, K. (2010). Changes in the $B$ anking System and Small Business Lending. Small Business Economics, 34(3), 293-308. http://dx.doi.org/10.1007/s11187-0089119-9

26) Wang, S., \& Zhou, H. (2004). Staged Financing in Venture Capital: Moral Hazard and Risks. J ournal of Corporate Finance, $\quad 10(1), \quad 131-155$. http://dx.doi.org/10.1016/S09291199(02)00045-7 